\title{
THE SURREAL CODES USED IN WRITTEN AND VISUAL MESSAGES BY NEW MEDIA AND TRANSFORMATION OF MEANING IN THE CONCEPTS OF PLAY-REAL
}

\author{
Olcay UÇAK \\ Aydin University, Turkey \\ olcayucak@aydin.edu.tr
}

\begin{abstract}
Daily language has changed with the rising popularity of social media. This usage of language developed within daily events and expressed through "surreal" signs is a part of social communication. All the codifications used structurally by language can be explicated by the concept of "exaggeration." To explain what is meant by exaggeration in this context, the concept of carnivalesque used by Mikhail Bakhtin in his literary criticism is taken into account. Bakhtin employed the term carnivalesque to define criticism characterized as "destructive" and "subversive" in the Middle Ages due to the ban of the critique of established values and social hierarchies. This concept designates the longing to symbolically subvert the hierarchy between the rulers and the ruled, the nobility and the common, the elite and the vulgar and the sacred and the profane. The study also utilizes Julia Kristeva's notions of intertextuality and intertextual relations. Using these concepts, it is demonstrated that the contents of news portals are composed much more like tabloids than as exhibitions of universal news criteria.
\end{abstract}

Keywords: Media, Myth, Exaggeration, Bakhtin, Carnivalesque

\section{YENI MEDYANIN YAZILI VE GÖRSEL ILETILERDE KULLANDIĞI GERÇEK-ÜSTÜ KODLAR İLE OYUN-GERÇEK KAVRAMLARINDAKİ ANLAM DÖNÜŞÜMÜ}

\section{ÖZ}

Kullanılan gündelik dilin sosyal medyanın yaygınlaşması ile birlikte değişim geçirdiği bir gerçektir. Gündelik olayların içerisinde kurgulanan ve "doğa- üstü" göstergelerle ifade edilen dilin bu kullanımı, sosyal iletişimin bir parçası durumundadır. Dilin yapısal olarak kullandığ 1 tüm kodlamalar "Abartı" kavramı ile açıklanabilir. "Abartı" terimini açıklayabilmek için yöntem olarak Mihail Bahtin'in edebiyat eleştirisi kuramında kullandığı Karnavalesk kavramı değerlendirilmektedir. Bahtin, Karnavalesk deyimini değerlerin ve hiyerarşilerin açıça eleştirilememesi nedeniyle Ortaçağ'da 'yıkıcı', 'tersyüz edici' ve 'karnavalsı' bir nitelik kazanan eleştiriyi tanımlamak için kullanmıştır. Bu kavram, abartıyı yaratan odakların iktidar ve yönetilenler, soylu sınıf ile halk tabakası, seçkin ile kaba, kutsal ve kutsal olmayan arasında kurulmuş bütün aşama düzenini, simgesel olarak altüst etme amacını belirtir. Çalışmada bu yöntemin dışında Julia Kristeva'nın metinlerarasılık ve metinlerarası ilişkiler kavramından da yararlanılmaktadır. Araştırma sonucunda, haber portalları içeriklerinde gerçek anlamda evrensel "haber değerleri" olan konuların seçilmesi yerine, bulvar gazeteciliğinin örnekleri sayılabilecek, sansasyon yaratacak kişi ve konuların gündeme getirilmeye çalışıldığı tespit edilmiştir.

Anahtar Kelimeler: Medya, söylence, abartı, bakhtin, karnavalesk

\section{INTRODUCTION}

The reality element stressed by the conventional media as a basic element of news criteria has started to change with the rising popularity of social media. The reality as presented in the new media conflicts with the reality as the primary element of news criteria ${ }^{1}$ in terms of the assessment of news content. Another case to be observed is the rising importance of quaintness amongst the news criteria

\footnotetext{
${ }^{1}$ The elements of news criteria: reality, novelty, importance, comprehensibility.
} 
instead of reality. One may notice this rising importance in stages of choosing the news subject, the usage of language in the news text and emphasizing of visual messages.

On the contrary of conventional media, the "reality" concept in the new media has been restructured within the frame of a different notion of reality. The necessity of verifying the resource and reasonability as the former prerequisites of reality to be accepted as a news criterion is likely to be questioned. While for the notion of conventional media, this renunciation of the element of reality in order to gain more popularity is a negative thing which deserves to be questioned and severely criticized, within the context of the expectations of new reader and spectator who use the social media with another perspective, the need for a new set of principles concerning media and journalism has arisen.

The stages of news collection and production and the rules of news language and editing that are still followed by the media is being transformed into a new format through the new media and this new format is adapted by a both reader-spectator and even writer mass whose adherence to this new media is paramount. In this essay it would be perhaps proper to call this mass as digital mass; hence from here on the followers of this new media is going to be named as digital mass. What are the expectations of this new interactive digital (numerical) mass from the media, a mass who does not need even the punctuation marks? What do they wish to read and watch? What kind of texts and news do they avoid to read and watch? It is certain that for social media researchers these questions are still without certainty due to their constantly changing nature and remain definitely to be answered. Does this reader-watcher-writer mass, bearing an interactive character, feel a need to design and redesign its own reality like a play maker? Does the fracture of the reality with the rapid advance of technology in the conception of journalism which is presented to public opinion with an alleged concern for reality by the conventional media has an effect in the emergence of the need for this new fictive reality?

This paper stems from the idea that the construction of this new reality which has started to emerge within the new media with the language, visual elements and music might be considered under the concept of play to which the humanity has an existential want.

"If you are wise, all men will be your friends and kindred, for you will be useful and good; but if you are not wise, neither father, nor mother, nor kindred, nor anyone else will be your friends."(Plato, 2014: 86). One can argue that the information has begun to be acquired relatively easily in our age; however, one cannot speak of a new generation who gets excited about acquiring or accessing to information. On the contrary, this new generation makes us think to redefine the rules of communication and reading, shows an interest in the unseen and mysterious rather than our readings which we call knowledge and employ to acquire truth and desires to have fun and play.

The concept of model reader defined in Eco's Interpretation and Overinterpretation is related with the different, hidden reality in Georg Simmel's account of secret. For Simmel, “... secret gives one a position of exception; it operates as a purely socially determined attraction. It is basically independent of the context it guards but, of course, is increasingly effective in the measure in which the exclusive possession is vast and significant... From secrecy, which shades all that is profound and significant, grows the typical error according to which everything mysterious is something important and essential. Before the unknown, man's natural impulse to idealize and his natural tearfulness cooperate toward the same goal: to intensify the unknown through imagination, and to pay attention to it with an emphasis that is not usually accorded to patent reality." (Eco, 2012: 56)

One may perhaps utilize Julia Kristeva's intertextuality concept here, for it describes a hermeneutical approach in which both the author and reader can write and read in a boundless freedom concerning the lectures aimed to attain real knowledge by reading (Cevizci, 2005: 1169).

In Eco, we encounter with a conception of reading which contributes to production and reproduction of a text as well as writing. For him, "... a text is an open-ended universe where the interpreter can discover infinite interconnections... Any text, pretending to assert something univocal, is a miscarried 
universe, that is, the work of a muddle-headed Demiurge (who tried to say that 'that's that' and on the contrary elicited an uninterrupted chain of infinite deferrals where 'that' is not 'that') (Eco, 2012: 57). Contrary to the today's reader who pursues excitedly the mysterious and unknown, Eco calls for the mystery of various different significations that may emerge during each reading and rereading of a text. The author defines the ideal reader as following: "The Real Reader is the one who understands that the secret of a text is its emptiness." (Eco, 20102: 57-58) The real reader or model reader who aims to discover the free thought and the richness of signification during reading is replaced by a new kind of reader which we call as "digital mass" who combines the reading and writing processes as if in a play. Moreover, the interactivity of the new media, as its prime superiority over the old one, allows digital mass to involve in the design-production stage of news as a first hand resource through writing, taking photos or shooting videos.

\section{PLAY AND HUMAN BEING}

This new play exhibited by digital mass is not a sub-code of culture but a spontaneous experience which predates, accompanies and influences culture. The play is also a voluntary act in terms of spontaneity which corresponds to Homo ludens (Playing Man) and frees people (Tekerek, 2001: 47). The digital mass of new media needs to follow the hot topics by jumping from one website to other (surfing) as well as to involve to the content providing process through its instantaneous reactions and comments.

The main reasons of the attraction of play can be enumerated as going beyond the daily life within a specific time and place, balance, opposition, weighing, solution, replacement, diversification and separation. The body language of people who are in their forties is obviously different from the body language of younger people while sitting in front of a computer or using a telephone.

Older people tend to be more helpless about digital media due to their lack of expertise over the computers; this can easily be seen from their troubled facial expressions and longer time they spend in front of the monitors. While the need to play as an integral part of our childhood period is being transformed into digital toys, and for the adults who can't adapt to this transformation it's without doubt much more easy to read a newspaper or to press the button of remote control.

Play, as the basic and essential desire of a human being, is an emancipatory and creative act situated at the source of all cultures and provides abstract thinking ability to human beings. According to Huizinga (2006), when the need to play is satisfied one begins to grow up by preparing to reality, confronting reality through play. Namely, he states that play can't be justified on a rational basis: "The very existence of play continually confirms the supra-logical nature of the human situation. Animals play, so they must be more than merely mechanical things. We play and know that we play, so we must be more than merely rational beings, for play is irrational." Huizinga introduces a new dimension to human culture as he brings a third one to the other two basic concepts which characterize human being: homo faber (making man), homo sapiens (thinking man), and finally, homo ludens (playing man).

From a Platonic perspective, "God alone is worthy of supreme seriousness, but man is made God's plaything... Therefore every man and woman should live life accordingly, and play the noblest games and be of another mind from what they are at present... Life must be lived as play, playing certain games, making sacrifices, singing and dancing, and then a man will be able to propitiate the gods, and defend himself against his enemies, and win in the contest." (Plato, "Laws" VII, 803. Huizinga, 2006: 38)

In famous Ottoman shadow puppetry Karagöz, similar to Plato's Laws, the playful aspect of life is mentioned within the context of "dream." The scrim used in the play is inspired from Sufism, and it may be considered as a screen of dream (Tekerek, 2001: 42). Boratav mentions some features of the

\footnotetext{
${ }^{2}$ Demiurge (anc. Gr.): an artisan-like figure responsible for the fashioning and maintenance of the physical universe.
} 
play such as voluntariness, freedom, being carried out in a specific time and place and delimits the play-concept as "the acts which recreate through entertainment." (Boratav, 1994: 232) Maybe for this reason the ritualistic account is indispensable to us.

Two most important functions of the play are striving for something and representing something. The play is a representation which is situated above, or at least independent from all cultures. An adult can play non-serious games just like a kid to have pleasure and get relaxed or endeavor more serious ones which eventuates from beauty or sanctity. Elmer Mitchell and Bernard Mason relate play to the human want of self-expression. In their opinion, one desires to live, to use one's abilities and to express oneself. This desire of self-expression is different from the instincts and results from life experience. The desire to express oneself may be elaborated as following: 1. Desire to try a new experience (ex. hunting, fighting, trying a new food); 2. Desire to have security; 3. Desire to react and respond (philanthropy, love, love for family, friendship, altruism, etc.) 4. Desire to be recognized; 5 . Desire to participate (membership, belonging to a community); 6. Desire to the beauty (color, shape, sound, mobility) and so on (Tekerek, 2001: 56 from And, 1948: 52).

The modern human, in other words, the digital mass can both play games in a virtual world and be recognized as someone else through these games and interactive participation and social media without leaving his or her room or house. Internet became the new playfield of the modern human to satisfy his or her basic need to play games, and allowing them to attain this field, the digital toys begin to gain significance for most of the people. The actions of virtual world (playing games or sharing in new media) create a magical illusion due to their realization outside of daily life. By virtue of the collective structures of these games and friend groups formed in the virtual world, enthusiasm and rhythm for a togetherness of the holy abundance rituals can be obtained.

The play is also a turning point that sparks the courage to create which potentially exists in a human being and cultivates/develops him or her. One express one's specific feelings-thoughts-fantasies with body-language-brain coordination through this revealed courage to create, and the necessary space to realize oneself is thus opened.

For Schiller, man is complete only if he plays; but he should not cheat and ought to participate sincerely and honestly to game:

"Hence the cheat or the spoil-sport shatters culture itself... It (play-element) must not be a false seeming, a masking of political purposes behind the illusion of genuine play-forms. True play knows no propaganda; its aim is in itself, and its familiar spirit is happy inspiration. The modern propaganda that seizes all fields of life feeds upon the hysterical reactions of masses. It is not thus to be accepted as the modern spirit of play even it emerges as a play-form, but a degenerated and false version of it." (Huizinga, 2006: 198)

\section{DIGITAL ENVIRONMENT: THE NEW PLAYFIELD OF POST-MODERN HUMAN}

While the conventional media has a more propagandistic structure, the new media brings interactivity. Hence the target audience may reach directly to the source of information through this system. It is a virtual play environment where the critical messages can be forwarded to thousands of people and verified immediately from the first source. In this virtual environment, propaganda becomes less dangerous, for in the conventional media the masses can easily be manipulated via propaganda due to their limited access to the sources of information. The propagandistic news with their misinformation (provide false or deficient news) and disinformation (deliberately misleading information announced publicly) features were to be detected and corrected more lately as we've seen in many examples in the past. Nowadays the new media, owing to its limitless diversity of resources, offers the possibility of comparing these kinds of news rapidly and economically with the real information and of transmitting more true news to target audience.

Fastness and multitasking as the most important characteristic features of the new media bring various problems. In a world of constant rush, Heidegger proposes to humanity to slow down to get free of the grasp of the capitalism. For Strain, slowness, "...can accommodate to the order of the things as it was 
before the capitalism with a respectful heed... This may be possible with philosophy (epistemology), with the constitutive perspective of philosophy, with its principle of creating new worlds. Media should give this opportunity of providing new perspectives to people to philosophy. This opportunity won't come from the capital that controls the media but the development and widely recognition of virtual media. Otherwise people continue to harbor within hollowness, to desperately live an unhappy life evading reality." (Strain, 2003)

If one who seeks an escape way in a world of constant rush can't slow down, with the influence of advertisement and media, he or she begins to get drawn into a world full of self-improvement methods, addictions and hollowness. In Taburoğlu's words, "advertisement and media specialists seek to approach to an ego full of complaints... As in all hollow thoughts, the material merges with spiritual and the visible fuses with invisible (Taburoğlu, 2011: 180).

Human being strives to find escape routes in the modern world of constant rush and hustle that does not allow desire of play, hence the normal and healthy development of a human being through play is at stake. In this context, the new media becomes one of the few playfields of the modern world. The new culture of play transforms consequently man into a technological work. The study fields of new media are the new forms of play now. For example, the celebrities of tabloid journalism have been converted into the relentlessly followed actors and actresses of new media. However, the rules of being followed have also been redefined. The extra thin bodies of women can be seen as examples of anorexia or men who seems always fit and in good condition may be set as role models.

Özgür Taburoğlu notices the quest for slowing down of humanity in an industrializing world of gaining pace: "To confront the hardships and problems of life with the reifying and hastening effects of capitalism has several results. The sudden transition from childhood into maturity creates a vacuum and one tries to fill this gap with excessive workout programs or self-development activities. Due to one's inability to slow down, one develops obsessions, twitches and fetishes and tends to get drawn in hollowness..." (Taburoğlu, 2011: 258)

So the women and men who are physically too perfect to be real as well as a luxurious life to which everyone tries to attain are interactively designed with the new media. Yoga, meditation, a conception of sports that is alien to play-concept and ethics code as well as the sportsman who has been turned into iconic figures such as Beckham all cooperate to create a new life style; hence the new media appears as an area of common values exhibiting changing cultural processes. The aliments they consume, the clothes they wear, the movies they watch, the books they read, the songs they listen to, their body language and the places they live start to constitute the new common values, in other words, make virtual the actual as soon as they appear on the new media.

On the other hand, the digital masses who desire to create new realities by taking refuge in plays head for the social media. The authors such as Homerus or Rabelais who have influenced people for hundreds or even thousand years chose to adorn and integrate their texts with myths, dreams and surreal images, regarding the need of human being to escape reality. Looking these authors, it seems inevitable that the new media must pay heed the basic needs of people such as tolerating the reality or preparing to innovations despite the developing technology. One can appropriate the given truths more easily when one is prepared to reality in a suitable manner to one's disposition; namely, through an entertaining discourse decorated with tales, dreams and myths.

The desire of a human being to constitute a fictional life entails the use of a new fictive language in the new media. The instructive language of the conventional media seems inappropriate for the modern media as the users of new media, namely digital mass doesn't want to be instructed; instead they long to be active and they need to think and live as they know and share their choices and deeds. The transitional language from the conventional media to new one should be natural as playing and sharing a game. The most suitable method of this transition seems also to be a playful one. One of the figures to follow in the matters of playful language and method is Rabelais. Rabelais succeed to be one of the rare authors who chose to instruct through entertainment by placing tenderly the high and holy ideas 
and concepts that humanity tends to be afraid to accept in a poetic expression such as "how happy was he who resisted to the end." (Rabelais, 2000: 252) Moreover, Rabelais sublimes peace, entertainment, friendship, knowledge, freedom and sincerity in a manner which might lead to creating new values to the one who tries to realize oneself in the new media. However, he presents this values not as an instructor but as a storyteller like he did in his famous work Gargantua, benefiting from exaggeration and surprise elements as if he recites a tale or story.

\section{EXAMPLES OF THE NEW MEDIA}

The new media begins to be indispensable via satisfying two crucial needs of a human being. These are the myths and beliefs lacked by urban people and the need to consume. In the examples of new media, it is seen that both of these needs are satisfied by countless resources.

The flaneur character of Benjamin's Passages (1993) who is a loafer, conformist guy can be related to modern new media audience. Thus we begin to see a similar of Benjamin's loafer guy who raises unproductivity to an aesthetical even political level in the technology-addict urban guy who aims to satisfy his or her needs without leaving the desk. Shopping becomes merely the precondition of survival for this new urban guy. Unlike the hedonist traveler of our time who plans to stroll in as many places and to see as many different cultures as he can, their consumer and traveler behavior involves a tragical, almost spiritual aspect in itself (Taburoğlu, 2011: 59).

The loafer conformist guy of Benjamin and the consumer of Taburoğlu meet on the economic news of media. The latest developments in economy and the increase and decrease of assets are the news of primary importance to be followed. However, one can come across irrational statements even in the economic departments of newspapers such as this piece of news dated December 12, 2014 on a national newspaper (www.milliyet.com.tr):

"Ghost Ship in the Harbor of Iskenderun"

"UK flagged ship named Aqua Hercules of 193 meters and thirty three thousand gross tons which came to the harbor of Iskenderun at 2012 for ROPAX services has been waiting anchored for 15 months due to the debts of its owners."

When we keep reading we understand that the ghost expression refers to the situation of tanker waiting without lights and crew.

\section{THE DANGER OF ORTHODOXY, HOLLOWNESS}

Post-modern, post-industrial is a period where accumulating and saving is merely prohibited. "The orthodoxies which are a certain type capital of the cultural accumulation degenerates rapidly." (Bourdieu, 1984). Orthodoxy is an intellectual accumulation, sedimentation; it is the petrified sense stabilized by blind belief and one of the basic materials of hollowness and superstitions. Superstitions necessitate the existence of orthodoxies, the fragments of sense resistant to questions. The beliefs invited unquestionably to orthodoxies, fetishes and forms of fanaticism constitute the basis for superstitions. (Taburoğlu, 2011: 77)

One of the examples taken from the website of national newspaper Sabah, begins with the following statement: "Many irrational, horrifying, supernatural things that are inexplicable by science happen in the world. Here are some examples of those events which left question marks in many minds:..." Many similar news were published between the last months of 2014 and January 2015 in the same website (www.sabah.com.tr).

"In 1945, an experienced archeologist named Waldemar Julsrud found little clay statuettes buried in the ground at the slopes of the mountain El Toro (Mexico)."

"In the New Zealand, the walls consisted of perfectly aligned stones which belong to an ancient empire are found. There isn't any information about the builders of these walls."

"The undecaying body found in the shrine of the Aşlkl Sultan who was martyred during the conquest of Kastamonu Castle around the beginning of 12th century amazes the visitors."

"The famous 'Kievan Cosmonaut' 
This figurine is the only finding found in Europe which exhibits 'space man' characteristics. It is very old."

"Orange flying objects were seen in Cambridge, England."

"This 15 years old boy literally weeps blood. The kid living in Tennessee, USA weeps blood uncontrollably three times a day."

Another example is from the website of Milliyet: It is a report about a statue which suddenly started to turn around itself after having been exhibited peacefully for 80 years in a museum in Manchester.

In the report Price states that, "I put the statue back in the exhibition closet and the next day again it turned around itself. We made a fast-forward playback and detected its movement obviously. This statue had stayed in a sarcophagus with a mummy for thousands of years." (www.milliyet.com.tr)

Moreover, the source of the popular news with a hit of 356,980 is a scientist:

British Egyptologist reminded ancient Egypt beliefs to explain the auto-movement of the statue: "Egyptians bury their dead with the items they used in their life in order to provide them with the necessary means in the after-life... Ancient Egyptians believed that if the mummy of the deceased one is destroyed, the statue will take his or her soul safely to the after-life. The reason for the movement of the statue may be this..."

However, the ordinary and routine knowledge may easily be degenerated within a network of information which always points different worlds and lives. Particularly in media, a surplus of information and visual materials in which one can't distinguish the right from the wrong emerges. For someone whose truths are constantly falsified, anything becomes instantly trendy or outdated (Taburoğlu, 2011: 78). One of the functions of the media may be remedied here: Can't the new media be the intermediary of the transformation of the actual one into a more dignified version which gives the true and correct information?

One of the most favorite topics focused by the new media is environmental issues and the promotion of environmental protection campaigns. With this context, the true aspect of so-called environmentalist and ecologist organizations and associations is revealed by the new media. The environment issue seems one of the most harmless matters to support and for the supporters and followers of these organizations, falling away from its true purpose, it may be seen as a reasonable way to socialize. "The refusal of these organizations -Greenpeace, 350.org and Sierra Club amongst them- to protest against the intensive animal farming shows the impotence of activists against the corporate power." (Hedges, 2014)

Nowadays urban population strives obsessively to rediscover and participate into the lost naturalness. Nature becomes a myth, a distant past, a place for a tale full of memories of the nostalgic times, a supplement which completes and integrates our void, our lack. One finds itself in a game of merging and separating with animals, plants, wild creatures and the strangers from distant lands. The natural is dreamt as a place that may be seen by moving away from here and now and returning from now to past (Strain, 2003).

The nature becomes a passive, accumulated, disclosed, and in Heidegger's words, "enframed" grandeur which is forced to be productive and which does not bloom or sprawl (Taburoğlu, 2011: 122).

For primitives, tales, myths and other kinds of hollow accounts become a part of tribal life. This hollowness that can take illustrated, visual, iconic, vivid and physical shapes returns occasionally to the daily reasoning like a specter, without getting completely lost in the logic and various abstractions. Contrary to their effort to leave them out, hollowness can merge into the life of the denizens of metropolis who have to live an expeditious life, and media precipitates this case. They return as the deliriums of the primitive mentality common to everyone. The existence of this primitive mentality is somewhat necessary. 
"Everyone has a strong primitive mentality. If this mentality disappears, poetical works, poetry, art, metaphysics and science will also disappear alongside with beauty and glory. This mentality symbolizes an indestructible thing in the human nature." (Levy-Bruhl, 2007: 29)

This situation which coincides with the primitive need for play is like a key to return from tolerance to reality to the art itself. "In the primitive mentality, a magic, fabulous accounts corresponding to a weird symbolism fill the gaps, accidental, indefinite fields. When the primitive mentality starts to operate, self-evident magic, myths, legendary weirdness cover the gaps which seems irrational. The weirdness which disturb the natural course of events is graced with this symbolism." (Malinowski, 2000: 30)

Supposing the primitive mentality functions as a catalyst between the human desire for truth and the desire for science and arts does not seem wrong. One who has to live with familiar patterns of reality but wants to investigate further needs these kinds of unordinary and unfamiliar patterns of thinking to attain new possibilities, findings, inventions and artistic perspectives. Erasmus associates this thinking beyond the borders of reason with folly.

\section{THE FREEDOM OF FOLLY}

Erasmus begins his work named In Praise of Folly in which he explained classical medieval thought as well as introduced his own understanding and wit as "For I am now in a humor to act...". He writes that instead of tyrannizing the reader he choose to imitate the elders who preferred the title of humorist and whose task is to celebrate the work of gods and heroes; but he declares that he preferred to praise the folly instead of gods and heroes (Erasmus, 2013: 14). He does not refrain from mocking the sophists who praise themselves as they grow older and stating that "only folly slows down the ephemerality of youth and expels the dull senility..." he begins to praise the folly as well as assert his own ideas and opinions about various matters in his own limitless area of freedom.

For Erasmus, the folly detracts one from reason and approaches him to his passions. The folly also saves one from two calamities which prevents him from recognizing the things in their entirety: shame and fear. Thus even the restrictions of medieval setting won't hinder him from explaining himself. Erasmus advises human being not to get too much wise in the comedy of life: "The difference between the fool and saint is while the former acts on passion the latter acts on reason." Therefore it is erroneous to associate the happiness with the real facts, for the happiness is associated with ideas and thoughts.

In his In Praise of Folly, Erasmus makes reference to all wise men and philosophers and recounts their inadequacies, characterizing the educators as most miserable of them, and he supposes that only the educators can overcome the difficulties through an amusing folly. "Despite their miserableness, they (educators) conceive themselves as the agent of noble deeds in so much that their essential source of happiness is their great confidence in their wisdom." (Erasmus, 2013: 84)

\section{MIKHAIL BAKHTIN'S CARNIVAL}

One of the cases which the new media prefers to accept without questioning their authenticity and temporality is the comic events created by a humorous language and approach. As a matter of fact, for digital mass, being comic begins to be the most important factor to be preferred. Being comic is amongst the most sensational, well accepted and favored qualities for new media.

According to Mikhail Bakhtin, one of the writers who illuminates us concerning the history of comic, "The plane of comic (humorous) representation is a specific plane in its spatial as well as its temporal aspect. Here the role of memory is minimal; in the comic world there is nothing for memory and tradition to do. One ridicules in order to forget. This is the zone of maximally familiar and crude contact; laughter means abuse." (Bakhtin, 2001: 178)

For Bakhtin, the four hundred years history of the appreciation, interpretation, and influence of Rabelais' work (Gargantua) is closely related to the history of laughter. In Gargantua, exaggeration is 
not for itself but to remark how relative is the measure and order in this game of creativity. One can see an astounding oscillation between imagination and real (Rabelais, 2012: 20).

In the history of laughter, Rabelais represents an important turning point of delimiting the Renaissance laughter conception. The Renaissance conception of laughter can be roughly described as follows: "Laughter has a deep philosophical meaning, it is one of the essential forms of the truth concerning the World as a whole, concerning history and man; it is a peculiar point of view relative to the world; the world is seen anew, no less (and perhaps more) profoundly than when seen from the serious standpoint. Therefore, laughter is just as admissible in great literature, posing universal problems, as seriousness. Certain essential aspects of the world are accessible only to laughter." (Bakhtin, 2005: 94) Some news have smiling and entertaining aspects even they originally intend to be serious reports whose authenticity deserves to be questioned:

"Thigh Bone in Mars?

A recent photograph sent by reconnaissance vehicle Curiosity from the planet Mars caused excitement amongst UFO researchers of the world. It is supposed that there is a human or animal bone in the photograph." (Al Jazeera, www.milliyet.com.tr)

"UFO in holiday! After examining the photographs taken by Oya Öztürk, Begüm Bilgiç and Emine Eren in Bodrum county of Muğla, authorities from Sirius Space Sciences Research Centre claimed that the object in the photos is an UFO." (www.milliyet.com.tr)

"The photo from Mars stirs excitement.

The photographs taken by the NASA Mars Science Laboratory Robot Curiosity which is at Mars on an expedition mission excites UFO contests." (www.milliyet.com.tr)

"The 'bright' anxiety in Nasuhoglu

Seyman brothers who saw the bright object falling near the village while watching the World Cup soccer game on TV took the object for a sign of 'Alien Invasion' and made their last prayers. Nowadays, Nasuhoglu village of Sandikll, Afyon witness an interesting contest. In the village consisting of merely 55 houses, the only topics of conversation are meteors, space objects and UFOs..." (www.milliyet.com.tr)

Mikhail Bakhtin describes carnival as the return of man to his natural, title-free state where the hierarchy, fear and etiquette are suspended; a free and sincere relationship develops between people; and where an awkwardness, a wild and primitive structure emerges with an experience outside of the flow of daily life (Bakhtin, 2001). These formulations and definitions make one to hope that the entertaining and carnivalesque mood which modern people needs as well as the most easy and democratic way to escape from the dullness of daily life are possible with the new social media. In social media the taboos, restrictions, hierarchy and etiquette are eliminated. The ghost photographs and news that we begin to see especially in the new media in which the interconnected mass constitutes a sense of belonging with the bodily touch of carnival continue to attract reader's, or to be more precise, watcher's attention. The hit numbers of these kinds of news prove us the amazing amount of attraction they catch.

However, as one can presume, these vivid news conceptions of the journalists who are responsible of providing realistic information about world contradict with the scientific facts. Because according to the article "Neurological and Robot-Controlled Induction of an Apparition", published in November 2014 issue of Current Biology, people's ghost belief stems from a fascinating particularity of human brain. According to the research cited in the article, an erroneous perceptive induction whose cause is still unknown creates an illusion of another's presence, called FoP (Feeling of a Presence). Another interesting finding of the research is that this illusion is also described by healthy people (Current Biology, 2014: 2681).

One of the examples is titled "The Ghost of Teresa Fidalgo Shook Instagram" (www.hurriyet.com.tr)

"The Ghost of Teresa Fidalgo That Shook Instagram Has Also Reached to Turkish Users

Early on Halloween a new ghost story got viral on the internet. This time the tale spreads mostly on Instagram. The users who got the message "I am the ghost of Teresa Fidalgo and I will haunt you forever unless you don't send this message to 20 other people," take a screen shot and share it on 
Instagram. The producer of short video "A Curva," a Portuguese named David Rebordao says that he completely invented this story for artistic purposes. However, many users who have already got in the mood of Halloween continue to share the spam-like message.

As one can see, it is not plausible to claim that all of the news on the new media is irrational but it is an interesting fact that even in the events whose date, time, place and source is evident, it gradually diverges from reality to catch attention of both the digital mass and the new media. This is an example of the events whose authenticity and source is evident may be reshaped and organized according to fictional images (www.hurriyet.com.tr)

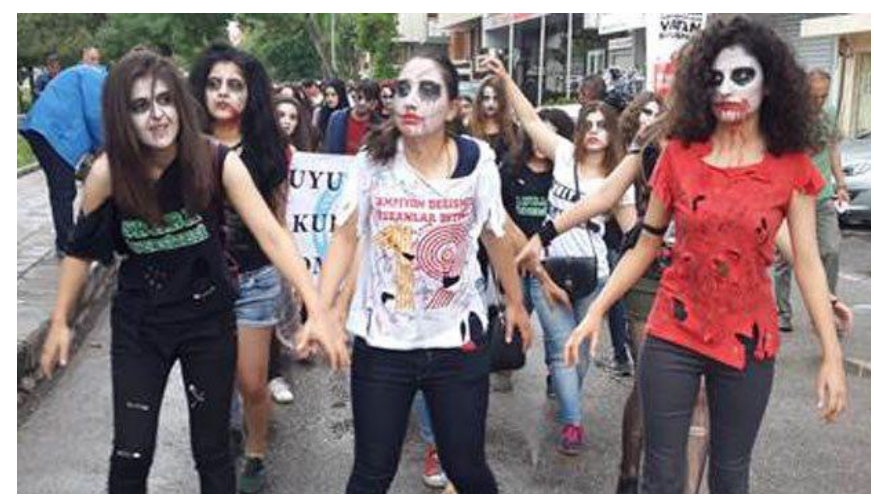

Image 1: www.hurriyet.com.tr

"Zombies against drugs. In the protest organized by Ankara University Student Council the students looking like zombies draw attention to the addiction of drugs. Don't use drugs, don't be a zombie."

\section{DIGITAL NEWS AND ETHICS}

In his Journalism and New Media, John V. Pavlik considers the transformation of news and journalism in the new media with its positive and negative aspects and informs the reader about the future of journalism (Pavlik, 2001: 133). A detailed discussion of one of the problems of future media can be found under the topic of "Producing Digital News" situated in section five named "Journalism Ethics and the New Media" of part two, "Transforming How Journalists Do Their Work?" For Pavlik, digital news producing raises various ethical questions about the verification of news content for their authenticity, since the number of controllers for each video gradually decreases because of technical developments and financial issues. The same reasons also make the unrealistic manipulation of audiovisual contents of the news more easy and accessible.

There are three ways of the digital image manipulation: add, cut and change (enlarge, merge) (Pavlik, 2001: 134.) Through these three methods non-existing objects can be added to visuals out of thin air, the size of existing objects in visuals can be changed and objects and details can be removed totally from visuals. Hence with the advance of digital technologies, the ethical problems of news producing are going to be multiplied and sometimes difficult situations can arise such as the manipulation of public opinion by producing unrealistic news through the means provided by digital technologies whose defects are unseen to the untrained eye.

\section{CONCLUSION}

One can conclude that the modern media desires to think outside the established intellectual and cultural borders like Mikhail Baktin's carnivalesque or deliver its messages through exaggeration like Rabelais's Gargantua. Apparently the plain and pure real does not seem to be sufficient for the modern digital mass; maybe modern man does not want to go outside the Plato's cave and find the truth. Instead he presumably desires to experience the deepest and tiniest remnants of his primitive life with mystery, he aspires to play, rather being Eco's model reader, he wants to be author of his own pages and to discover new readers, and he maybe needs to live with readers.

Most people like mystery and legends and want to read and discover them. It seems easier to obtain knowledge from them. In order to reach this new reader-watcher and writer mass who we called above digital mass, one should try to understand this new language of the new media, to analyze this new 
visual language. A need for a new reader who can combine the rhetoric of Aristotle and the sense of mystery and wonder in Plato's cave with the discovering motive of Homerus and emancipating content of Rabelais's exaggeration, the carnivalesque enthusiasm of Bakhtin with the scrupulousness of Eco's real reader, a need for a new reader who can find a common ground with common sense seems to rise. For, a new language which combines the advantages of technology concerning obtaining information with the visual graphical elements seems to rise, a language which we needed since the primitive man and which is going to endure as a visual carnival after blending the poetry with myth and ideas.

The reporters of new media should now seek how to transmit reality and realize the digital mass that does not anymore pursue the truth like an enthusiastic reader and for whom the matter is not the real itself but the style of it. They should seek to understand how to transmit the non-absolute truth, integrating it with visualization. They should try to develop this new reality, and strive to make it attractive like a game through the presentation of truth with the new communication and reporting styles. The reporter or the writer ought to find which values should be underlined and presented by the new media. Sometimes, searching old values and examining old writers and works that make people happy and reflect upon life and world might be useful alongside with the constantly changing news feed for the auto-development of media. Before creating the needed values for humanity, it might prove fruitful to remember the fables and plays that tell us the core and crucial characteristics of human life since the ancient times. They will always continue to be the bright and important sources of human values.

People will need to hear the news as they used to be. The important thing is to popularize the texts and videos that remind us our humanity while satisfying the need for information through both informative, educative and entertaining sources, since the news is a potent means to affect the society's public opinion and values. Consequently, since they conceive the digital as a playground, the digital mass that seems to share power with the media in the future does not only want to know but also to learn the comic and mysterious, and to join the party; in a word, they change.

\section{REFERENCES}

And, M. (1974). Oyun ve Büyü, İstanbul: Türkiye İş Bankası Yayınları, I.B.

Bakhtin, M. (2001). Karnavaldan Romana, Istanbul: Ayrıntı Yayınlart.

Bakhtin, M. (2005). Rabelais ve Dünyası, Istanbul: Ayrintı Yayınları.

Benjamin, W. (1993). Pasajlar, trans. Ahmet Cemal, Istanbul: YKY.

Boratav, P. N. (1994): 100 Soruda Türk Folkloru, Istanbul: 3.B., Gerçek Yayınevi.

Bourdieu, P.(1984). Distinction; A Social Critic of the Judgment of Taste, trans. Richard Nice, New York: Routledge \& Paul Kegan.

Cevizci, A. (2005). Felsefe Sözlüğü, İstanbul: Paradigma Yayıncılık.

Current Biology, (2014). Neurological and Robot-Controlled Induction of an Apparition, Volume 24,

Issue 22, 17 November, Pages 2681-2686,

http://www.sciencedirect.com/science/article/pii/S0960982214012123\#bib1 29.12.2014

Erasmus, D. (2013) Deliliğe Övgü, (3 ${ }^{\text {rd }}$ ed.), İstanbul: Oda Yayınlart.

Hedges, C. (2014). Gezegeni Kurtarmak, Her Ögü̈nde Biraz, trans. Ömer Madra, Yurt Gazetesi, 30 Kasim 2014.

Huizinga, J. (2006). Homo Ludens, trans. Mehmet Ali Kllıçbay, (2 $2^{\text {nd }}$ ed.)., İstanbul: AyrıntıY.

Levy-Bruhl,Lucien, (2007). Illkel Toplumlarda Illkel Deneyim ve Simgeler, trans. Oğuz Adanır, Ankara:

Doğu-Batı.

Molinowski, B. (2000). Büyü, Bilim ve Din, trans. Saadet Özkal, İstanbul: Kabalcl.

Murakawa, K.(1957). Page [385] of 385-415, Historia: Zeitschrift für Alte Geschicht... > , Bd. 6, H. 4, Oct., > , http://www.jstor.org/stable/4434542 22

Pavlik, j.J. (2001). Yeni Medya ve Gazetecilik, trans. Müge Demir and Berrin Kalsin, Ankara: Phoenix Yayinevi.

Platon, Symposion-Lysis, (2014). trans. Sabahattin Eyüboğlu and Azra Erhat, $11^{\text {th }}$ ed... İstanbul: Türkiye İş Bankası Kültür Yayınları. 
The Turkish Online Journal of Design, Art and Communication - TOJDAC January 2017 Volume 7 Issue 1

Rabelais, François, (2012). Gargantua, trans. Sabahattin Eyüboğlu, Azra Erhat, Vedat Günyol, $7^{\text {th }}$. ed., İstanbul: Türkiye İş Bankası Kültür Yayınları.

Simmel, G. (2012). The Secret and the secret society, The Sociology of Georg Simmel, trans. ed. Kurt H. Wolff (New York, Free Press, 1950), s.332-333.

Eco, Umberto (2012). Yorum ve Aşırı Yorum, 6th. edition, İstanbul: Can Yay.

Strain, E. (2003). Public Places, Private Journeys: Ethnography, Entertainment, and the Tourist Gaze, New York: Library Congress.

Taburoğlu, Ö.(2011). Kent Efsaneleri Zamanımızın Batıl İnançları ve Takıntıları, Doğu Batı Yay.

Tekerek, N. (2001). Popüler Halk Tiyatrosu Geleneğimizden Çağdaş Oyunlarımıza Yansımalar, Ankara: T.C. Kültür Bakanlığı Yayınları.

\section{Internet}

http://www.milliyet.com.tr/iskenderun-limani-nda-hayalet/ekonomi/detay/1954260/default.htm

14.10.2014-13:55 Milliyet.com.tr » Ekonomi » Haber (12.12.2014)

http://www.hurriyet.com.tr/dunya/27492369.asp (12.01.2015)

http://www.sabah.com.tr/fotohaber/dunya/dogaustu_aciklanamayan_olaylar 15.10.2014

http://www.milliyet.com.tr/fotogaleri/36351-yasam-sirri-cozulemeyen-gizemli-olaylar/5

(15.10.2014)

http://www.milliyet.com.tr/-mars-ta-kalca-kemigi-iddiasi-gundem-1930072/ (24.08.2014)

http://www.milliyet.com.tr/ufo-tatilde--gundem-1909539/(10.7.2014)

http://www.hurriyet.com.tr/gundem/29087194.asp (23.05.2015)

Image 1

http://www.hurriyet.com.tr/uyusturucu-kullanma-zombi-olma-29091757 (25.05.2015) 